\title{
Miłosierdzie wobec osób uzależnionych. Garść refleksji kapelana oddziału odwykowego w kontekście Wielkiego Jubileuszu Miłosierdzia
}

\section{Miłosierdzie na oddziale odwykowym}

Miłosierdzie ma wiele twarzy. Chcę wspomnieć o dwóch jego istotnych elementach. Pierwszym jest dowartościowanie człowieka, a drugim przebaczenie.

Święty Jan Paweł II w encyklice Dives in misericordia [dalej: DM] pisał tak:

Jezus nade wszystko swoim postępowaniem, całą swoją działalnością objawiał, że $w$ świecie, w którym żyjemy, obecna jest miłość. Jest to miłość czynna, miłość, która zwraca się do człowieka, ogarnia wszystko, co składa się na jego człowieczeństwo. Miłość ta w sposób szczególny daje o sobie znać w zetknięciu z cierpieniem, krzywdą, ubóstwem, w zetknięciu z całą historyczną 'ludzką kondycją', która na różne sposoby ujawnia ograniczoność i słabość człowieka, zarówno fizyczną, jak i moralną. Właśnie ten sposób i zakres przejawiania się miłości nazywa się w języku biblijnym miłosierdziem. ( $\left.\mathrm{DM}_{3}\right)$

1 Ks. Mirosław Żak, dyrektor Studium Apostolstwa Trzeźwości, kapelan w Wojewódzkim Ośrodku Terapii Uzależnień i Współuzależnienia przy Szpitalu Specjalistycznym im. dr. J. Babińskiego w Krakowie. 
Miłość w zetknięciu z biedą to jest miłosierdzie, jednak nie zawsze - czasem może być naiwnością lub głupotą. Miłość powinna być mądra, roztropna.

Dalej, komentując przypowieść o miłosiernym ojcu (znaną też jako przypowieść o synu marnotrawnym), papież pisał:

Miłość taka zdolna jest do pochylenia się nad każdym synem marnotrawnym, nad każdą ludzką nędzą, nade wszystko zaś nad nędzą moralną, nad grzechem. Kiedy zaś to czyni ów, który doznaje miłosierdzia, nie czuje się poniżony, ale odnaleziony i 'dowartościowany’. Ojciec ukazuje mu nade wszystko radość z tego, że 'się odnalazł', z tego, że 'ożył. A ta radość wskazuje na dobro nienaruszone: przecież syn, nawet i marnotrawny, nie przestał być rzeczywistym synem swego ojca; wskazuje także na dobro odnalezione z powrotem: takim dobrem był w wypadku marnotrawnego syna powrót do prawdy o sobie samym. (DM 6)

To jest bardzo ważne stwierdzenie: owocem miłosierdzia ma być powrót do prawdy o samym sobie.

Jeszcze jedno ważne stwierdzenie:

[...] relacja miłosierdzia opiera się na wspólnym przeżyciu tego dobra, jakim jest człowiek, na wspólnym doświadczeniu tej godności, jaka jest jemu właściwa”. (DM 6)

I ostatnie:

W swoim właściwym i pełnym kształcie miłosierdzie objawia się jako dowartościowywanie, jako podnoszenie $\mathrm{w}$ górę, jako wydobywanie dobra spod wszelkich nawarstwień zła, które jest w świecie i w człowieku. (DM 6)

Obecnie większości ludzi mówienie o miłosierdziu kojarzy się z postacią świętej siostry Faustyny, natomiast papież w tej encykli- 
ce w ogóle nie odnosi się do jej Dzienniczka, ale kładzie ogromny nacisk na godność człowieka; mówi, że istotą miłosierdzia jest odbudowanie godności człowieka, postawienie go na nogi, powiedzenie mu: „Jesteś kimś. Bez względu na to, co w twoim życiu się wydarzyło, co zrobiłeś, nie przestajesz być kimś - bo Chrystus oddał za ciebie życie, bo stał się człowiekiem, stał się solidarny z człowiekiem, stając się jednym z nas". I to jest ta dobra nowina, to jest ewangelizacja: dobra nowina o człowieku, że każdy z nas jest kimś, bo Bóg stał się człowiekiem, oddał za nas swoje życie na krzyżu. To jest taki fundament, do którego ciągle musimy wracać, który musimy sobie uświadamiać: że istotą miłosierdzia jest dowartościowanie człowieka, nawet gdyby nie udało się mu pomóc - zwłaszcza gdy chodzi o sytuację uzależnienia. Bo prawda jest dość smutna: w Polsce mamy ponad milion ludzi uzależnionych i wielu $\mathrm{z}$ nich nie uda się uratować; wielu nigdy nie stanie w prawdzie i nie uzna swojego zniewolenia; wielu przedwcześnie umrze.

Drugim bardzo istotnym elementem miłosierdzia jest przebaczenie. Ten jego aspekt bardzo mocno i często podkreśla w swoim nauczaniu ojciec święty Franciszek. Jezus powie o sobie, że nie przyszedł na świat po to, aby świat potępić, ale po to, by świat zbawić. W chwili, gdy był przybijany do krzyża, modlił się: „Ojcze, odpuść im, bo nie wiedzą, co czynią”. A pierwszym darem po zmartwychwstaniu było ustanowienie sakramentu pojednania.

Te dwa elementy miłosierdzia wydają się bardzo istotne i pomocne w procesie trzeźwienia. Uzależnieni od alkoholu mają bowiem ogromnie zaniżone poczucie wartości, a także ogromne poczucie winy.

W mojej posłudze wobec uzależnionych szczególnie zwracam uwagę na te dwa elementy, zwłaszcza na dowartościowanie chorego na chorobę alkoholową. Nigdy nie zapomnę jednego z pacjentów, który wychodząc z oddziału, podziękował mi za to, że nim nie pogardziłem i podałem mu rękę. Podnoszeniu poczucia wartości służą m.in. rekolekcje, jakie systematycznie są prowadzone dla pacjentów 
oddziału odwykowego. Zawsze uczestniczy w nich kilkadziesiąt procent spośród nich. W podnoszeniu poczucia wartości odwołuję się do wartości religijnych, wskazując, że dla Boga każdy człowiek, bez względu na to, co zrobił w życiu, jest cenny. Bardzo ważny jest także bezpośredni kontakt z pacjentami, naznaczony szacunkiem i akceptacją.

\section{Miłosierdzie wobec alkoholików w życiu codziennym}

Pierwszym krokiem w miłosierdziu wobec tych ludzi jest zmiana naszego myślenia. Co się musi w nim zmienić? Przede wszystkim trzeba uświadomić sobie jasno, że alkoholizm jest chorobą. Analogicznie, gdy ktoś ma zapalenie płuc, to się go leczy. A to, że chodził boso po śniegu, to jest przyczyna. My nie oceniamy zapalenia płuc. Możemy oceniać to, że on chodził boso po śniegu. Tak samo jest $\mathrm{z}$ alkoholizmem i piciem. Ocenie moralnej poddawany jest fakt picia. Alkoholizmu nie ocenia się moralnie, alkoholizm się leczy.

Alkoholizm jest chorobą i nigdy nie spotkałem nikogo - pracuję w Kobierzynie 18 lat - kto by pił dlatego, że chce być alkoholikiem. To się dzieje niezależnie od woli człowieka. Ocenie moralnej można poddawać picie, a tutaj motywacje mogą być bardzo różne. Ktoś sięga po alkohol, bo ma nieukształtowaną tożsamość (a niestety młody człowiek nie może mieć ukształtowanej tożsamości, chce być inny) albo cierpi, coś go boli, życie go boli i dlatego pije. Bo we wszystkich uzależnieniach jest mechanizm nałogowego regulowania uczuć.

Często mówi się, że alkoholizm to choroba CUD - ciała, umysłu i ducha. Można posłużyć się schematem pokazującym, że my jako ludzie funkcjonujemy na czterech płaszczyznach. Są to:

I. ciało;

II. psychika (myślę, czuję); 
III. płaszczyzna społeczna;

IV. płaszczyzna duchowa (sens, wartości).

Pierwsza płaszczyzna to nasze ciało. Trzeba o nie dbać - spróbowalibyśmy nie jeść, nie spać, nie myć się...! Drugi poziom to nasza psychika. Są w niej dwa istotne elementy: myślę (uczę się, pamiętam itd.) i czuję. Trzecia płaszczyzna: społeczna, czyli relacje z ludźmi. I czwarta: duchowa - tu jest miejsce na wiarę, sens, wartości, jakimi się w życiu kierujemy.

Zdrowy człowiek to taki, u którego między tymi płaszczyznami panuje pewna harmonia, ład, a płaszczyzna duchowa nadaje kierunek pozostałym. Jakie są podstawowe wartości dla człowieka wierzącego? To wiara, nadzieja i miłość; cztery cnoty kardynalne: roztropność, sprawiedliwość, umiarkowanie i męstwo; i jeszcze trzy: prawda, wolność i pokora.

Które płaszczyzny są dominujące w dzisiejszym świecie? Masz być piękny, silny, zdrowy; masz mieć wiedzę; masz się dobrze czuć („kupisz sobie proszek X, będziesz się dobrze czuć). Natomiast chrześcijaństwo mówi: nie dobre samopoczucie jest najważniejsze, bo niekiedy to, co dobre, wcale nie jest zbyt przyjemne. Gdy dziecko jest chore, to czasem trzeba wziąć je do chirurga i ciąć. Boli? Boli. Ale to jest dobre - jeśli nie będziemy leczyć, to umrze. I kierujemy się w życiu wartościami, a nie odczuciami.

Natomiast w uzależnieniu, każdym bez wyjątku, jest tak, że zaczyna dominować płaszczyzna psychiczna, a przede wszystkim to, żeby dobrze się poczuć. Gdyby każdy wypity alkohol kopał po kręgosłupie dolnym, to nie byłoby alkoholików. Ale dzieje się tak, że po wypiciu tej substancji zmienia się samopoczucie, myślenie o sobie, tożsamość, rozumienie siebie i świata. Czyli pod wpływem alkoholu osoba pijąca inaczej się czuje, lepiej się czuje. Czyli... jest szczęśliwa. Jest jej dobrze. Każdy, kto chce jej to zabrać, to wróg. A jeżeli chcą mi zabrać to, co mi dobrze robi, to się bronię - w różny sposób. Dlatego pojawiają się agresja i atak, gdy ktoś chce zabrać alkoholikowi alkohol - bo jemu jest $\mathrm{z}$ tym dobrze. Wszyscy inni wokół cierpią - ale jemu jest 
dobrze. Ten „dobrostan” może trwać przez wiele lat, a gdy pojawią się bolesne konsekwencje picia, to mechanizm nałogowego regulowania uczuć jest już tak rozwinięty, że trudno z niego wyjść. Picie stało się jedynym sposobem przeżywania przyjemności.

Do tego dochodzi drugi mechanizm, tzw. system iluzji i zaprzeczeń, czyli zaburzone myślenie, które idzie w kierunku obrony swojego picia. Osoba uzależniona potrafi znaleźć tysiące argumentów, żeby usprawiedliwić nałóg. Generalnie argumenty są logiczne, ale nieprawdziwe. Logiczne: na pytanie „Dlaczego wypiłeś?” ktoś odpowiada „Bo przyjechała delegacja, szef poprosił, żebyśmy dłużej zostali, przy okazji postawił drinka”, zaś na kolejne: „A ile wypiłeś tych drinków?” - „Jeden, może dwa”. A ledwo stoi na nogach. Logiczne? Logiczne: delegacja itd. Ale nieprawdziwe: bo to były nie dwa drinki, tylko dwie flaszki, i nie delegacja, tylko kumple.

To są takie dwa mechanizmy psychologiczne funkcjonujące w każdym bez wyjątku uzależnieniu. Wszyscy je mamy: każdy z nas chce odczuwać przyjemność (regulowanie uczuć) i każdemu z nas trudno przyznać się do grzechów i błędów (mechanizm iluzji i zaprzeczeń). Co Adam odpowiedział na pytanie Boga: „Gdzie jesteś?” - „Przestraszyłem się, bo jestem nagi”; chciał w ten sposób uciec przed przykrymi uczuciami. A potem zrzucił winę na Ewę: „To Ewa”. A Ewa? Odrzekła: „Wąż mnie zwiódł”. Szukanie usprawiedliwień. Tylko podczas spowiedzi mówimy: „To ja zgrzeszyłem”. Nie ktoś tam, tylko ja. Spowiedź uzdrawia, jeżeli jest zbudowana na prawdzie. Stąd osoby uzależnione to mistrzowie manipulacji i kłamstwa. Dlatego w okazywaniu miłosierdzia trzeba wiedzieć, z kim ma się do czynienia.

To jest ważne w jakiejkolwiek interwencji: trzeba sobie zdawać sprawę, z kim się spotykamy. Jemu z alkoholem jest dobrze. Choroba się rozwija przez wiele lat, choć gdy upija się nastolatek, może się rozwinąć w ciągu kilku miesięcy (kobiety też szybciej się uzależniają). Ale gdy dorosły mężczyzna pije włoskie wino, to choroba może się rozwijać przez trzydzieści lat - drzewko będzie sobie rosło, ale nie będzie jeszcze przykrych objawów. Po trzydziestu latach mogą 
się pojawić symptomy typu: trzęsące się ręce, zespół odstawienia, pocenie, lęki itd. Ale przez te trzydzieści lat jemu $\mathrm{z}$ alkoholem jest po prostu dobrze! Pije coraz więcej, ale jemu jest z tym dobrze. Czyli: co trzeba zrobić, żeby przestał pić? Trzeba sprawić, żeby z piciem było mu źle. Dopóki nie będzie cierpiał, dopóki go picie nie zaboli, dopóty nie ma na to szans.

Bo te mechanizmy, poprawianie sobie samopoczucia i zaburzone, chore myślenie, są tak mocne, że dopóki ktoś nie będzie poważnie cierpiał z powodu swego picia, dopóty właściwie nie ma szans, żeby coś z tym zrobić. Taka jest prawda uzależnienia, prawda tej choroby. I stąd mówi się o tzw. twardej miłości, czyli o stworzeniu takich okoliczności, takiej sytuacji, w której osoba uzależniona będzie ponosić bolesne konsekwencje swojego picia - łącznie z tym, że będzie głodna, brudna, że siedzi w więzieniu itd. Czy każda operacja się udaje? Nie każda. Z tych iluś setek tysięcy zaledwie 20 proc. korzysta z pomocy - reszta przedwcześnie umrze. Albo przestanie pić, albo umrze, nie ma innego wyjścia. Stąd w wymiarze społecznym trzeba zrobić wszystko, by ludzie się nie uzależniali.

Stawiać wymagania, stawiać jasne granice - ale z drugiej strony musi być miejsce na to, żeby nie poniżać człowieka, żeby go nie przekreślać, żeby nie uwłaczać jego godności. Potrzebne są dwie rzeczy: to stawanie w prawdzie oraz prowadzenie do niej: jesteś chory, jesteś uzależniony, powinieneś się leczyć, powinieneś skorzystać z pomocy, bo właściwie nie ma innej drogi. Sam sobie nie poradzisz, choroba rozwija się wiele lat, jesteś w chorych schematach, nie jesteś w stanie sam prawidłowo funkcjonować. $Z$ drugiej strony taka interwencja jak odmówienie pomocy czy mówienie prawdy będzie się spotykać z agresją, bo się zabiera coś, co jest dla tego człowieka ważne, wokół czego kręci się jego życie. A jednocześnie potrzeba tego okazywania szacunku, jakiegoś docenienia, dowartościowania. Spotkałem się też z sytuacjami, gdzie dobro było taką okolicznością, że ktoś zaczął coś robić ze swoim życiem, zaczął się zmieniać, zaczął trzeźwieć. Słyszałem opowiadanie jednego terapeuty: mężczyzna, który 
był dyrektorem kopalni węgla na Śląsku, na skutek uzależnienia znalazł się na hałdzie, w budce, usmarowany... Wylazł z tej budki, by szukać kolejnej dawki alkoholu. I zobaczył dziecko. Dziecko z jabłkiem; dzieciak, wystraszony, wyciągnął rączkę z tym jabłkiem w jego kierunku. I to był taki strzał, w którego wyniku on się otrząsnął i zaczął szukać pomocy, stanął na nogi z powrotem, wrócił do normalnego życia.

Potrzeba więc dwóch rzeczy: $\mathrm{z}$ jednej strony sięgnięcia dna, a z drugiej - światła. Stawianie człowieka w prawdzie, a jednocześnie ogromny szacunek. Jak w studni: jest dno, ale też widać wyjście. Jeśli ktoś podejmie ten trud, by się drapać ku światłu, to jest szansa, że będzie normalnie funkcjonował.

\section{Świadectwo osoby bezdomnej}

Od kiedy pamiętam, bardzo się bałem i wstydziłem. Ojciec wyjeżdżał na delegacje, czekałem wtedy prawie tydzień, aż wróci; cierpiałem, kiedy tato nieraz wracał do domu pod wpływem alkoholu. Gdy to widziałem, mówiłem sobie: „Nigdy w życiu nie będę taki jak on! Będę wspaniałym ojcem, mężem, pracownikiem". Okazało się, że mój tato nie był alkoholikiem, to ja nim zostałem.

Do momentu uzależnienia „spotkałem się" $\mathrm{z}$ alkoholem cztery razy. W wieku pięciu lat, kiedy dziadek rozlewał swojskie wino do butelek, powiedział „pociąg sobie”. Wino było słodkie, wąż czerwony. Zapamiętałem ten dzień bardzo dokładnie, ze szczegółami. Kiedy miałem 15 lat i skończyliśmy ósmą klasę, moi koledzy postanowili uczcić naszą tzw. dorosłość - piwem. Wypiłem ze dwa łyki, bo nie smakowało, ale bałem się, wstydziłem i nie umiałem odmówić, żeby się znowu ze mnie nie śmiali. Byłem jeszcze wtedy niskiego wzrostu $(148 \mathrm{~cm})$, nosiłem okulary, świetnie się uczyłem, nie paliłem, nie wagarowałem, nie przeklinałem - moi koledzy bardzo mi dokuczali. Wtedy też chyba dostałem pierwszy teleg ram od Pana Boga. Na basenie na głębokości $110 \mathrm{~cm}$ koleżanka zachłysnęła się wodą, podałem 
jej rękę. Zaczęło nas wciągać. Ona oplotła mnie jak wodorost, a ja się właściwie tylko odbijałem i łapałem powietrze, bo się wstydziłem zawołać o pomoc, żeby znowu się nie śmiali... Kiedy już umierałem, zobaczyłem jakby nagrany film ze swego życia, który mi się cofnął do okresu, gdy miałem dwa lata (czas jakby nie istniał). Pamiętam strach, a potem moje wdanie w myślach - „Boże, przecież ja mam dopiero 15 lat! Niczego w życiu nie zrobiłem, niczego nie osiągnąłem... Zginąć na oczach tylu ludzi, w taki piękny dzień, w taki głupi sposób”. To mam nagrane na twardym dysku, nie zmieniłem ani słowa. Jak zostaliśmy ocaleni? Nie wiem. Znaleźliśmy się przy brzegu. W zeszłym roku po 44 latach spotkałem tę moją koleżankę i pytam ją: „Słuchaj, Danka, powiedz mi, dlaczego ty się nie darłaś?! Przecież byśmy utonęli”. „Bo się bałam, że jak się wyda, to mnie ojciec zabije" - odpowiedziała. W tamtym domu panowała przemoc. Mówię o tym, bo już wtedy było nade mną miłosierdzie Boga, którego nie widziałem... Takich zdarzeń miałem więcej i wydawało mi się, że ja faktycznie jestem jakiś nadzwyczajny, może nawet nieśmiertelny? A pycha rosła.

Trzeci raz zostałem „trafiony”, kiedy miałem 16 lat. Siostra była na kolonii w Zubrzycy Górnej, ja mieszkałem obok, na kolonii się żywiłem. Mieli tam jakąś imprezę. Lekarz z tej kolonii zapytał, ile mam lat. Odpowiedziałem, że 16. „To ty jesteś już dorosły i możesz się z nami napić”. Bardzo chciałem być dorosły. Wypiłem, chociaż się bałem. Wtedy też poczęstowali mnie pierwszym papierosem. Następnego dnia kupiłem już paczkę. Czułem niesmak, że nie umiałem odmówić alkoholu i papierosa, a może nie chciałem? Ale wtedy czułem się dumny, że zostałem zaproszony w dorosłe życie.

Czwarty „strzał” alkoholowy w 17 roku mojego życia dopadł mnie w imieniny Jerzego. Solenizant, mój kolega szkolny, obchodził imieniny swoje i ojca. Przyniósł pół litra wódki. Nie chciałem pękać ze strachu i wstydu, wypiliśmy, popijając kranówką i piwem w barze. Zerwał mi się film, a następnego dnia śmiało się ze mnie całe osiedle, bo chciałem przewracać wieżowce, bić napotkanych ludzi i schodzić 
z balkonu trzeciego piętra bez spadochronu. Potworny kac, temperatura prawie 40 stopni, dziesięć dni zwolnienia. Symulowałem ból żołądka. Pierwsze pytanie lekarki w szkole: „Piłeś?”. „A skąd! Nigdy w życiu nie piłem” - odpowiedziałem. Przecież musiało śmierdzieć ode mnie jak z bimbrowni, taka to choroba zakłamania. Ale wtedy stała się rzecz straszna - straciłem radość życia. Wszystko przestało mnie interesować. Konkursy recytatorskie, które wygrywałem, i olimpiady, które wygrywałem, i gra na gitarze, i śpiewanie, i góry. W szystko. Zanurzyłem się w alkoholu na 25 lat. Alkohol stał się główną treścią mojego życia. Znalazłem się na równi pochyłej albo, jak czasami mówię, na karuzeli śmierci, która kręciła się coraz wyżej, coraz szybciej i zabierała mi coraz więcej.

Pierwszy efekt - oblałem maturę, a gdy ją poprawiłem, nie dostałem się na studia, z każdej pracy mnie zwalniali, same straty. Byłem tak bezsilny i bezradny. Pamiętam, co ten alkohol ze mną wyprawiał. Na kacu szedłem do pracy, byłem kierownikiem transportu. Dwudziestu kierowców na mnie czekało, a ja nagle słyszę, jak stado ptaków, które siedziało na drutach, krzyczy na mnie: „głupi Wacek, głupi Wacek!”. „Kto jest głupi?!” - poszukałem jakiegoś kamienia, rzucam do tych ptaków. A jeden był uparty, siedzi i się drze: „głupi Wacek, głupi Wacek!”. „Ja ci dam! Obetnę ci tego słupa, jutro nie będziesz miał na czym siedzieć!”. Oczywiście spóźniłem się do pracy. Jak teraz na to patrzę, to nie wiem, czy płakać, czy się śmiać. Ja żyłem w jakimś durnym świecie. Miałem omamy wzrokowe i słuchowe, że nie umarłem, to cud. Widzę miłosierdzie Boże.

Nadszedł czas, że chciałem przestać pić, ale im bardziej chciałem, tym bardziej nie mogłem. Chodziłem do przychodni przeciwalkoholowej przymuszony przez ojca, który powiedział, że mnie wywali $\mathrm{z}$ domu (wróciłem do domu rodzinnego, bo wszystko zdążyłem już przepić). Tam, gdy mówili mi prawdę, to tak bolało, że piłem jeszcze więcej. I znalazłem się na ulicy, ojciec już nie mógł ze mną wytrzymać... Byłem na dnie: głodny, nie miałem pieniędzy, spałem gdzieś w piwnicy, piłem tam wodę z kranu i pomyślałem - są święta Bożego 
Narodzenia, pójdę do domu mojego ojca i poproszę go, żebym te święta mógł spędzić z rodziną. Ojciec powiedział, że pijanego nie chce widzieć. Więc wytrzymałem i nawet zostałem kilka dni. Było tak cudownie. Zaraz po świętach przyszedł ksiądz po kolędzie. Mój ojciec nie wytrzymał i powiedział, że im piekło na ziemi urządziłem - najpierw we własnym domu, w swojej rodzinie, a teraz jeszcze spadłem im na głowę i mają już dość takiego życia. Z bólu i wstydu wykrzyczałem: „Co ty możesz o tym wiedzieć, przecież mnie to toczy od środka jak rak!”. Ten kapłan, wychodząc, ujął moje ręce w swoje dłonie, pochylił się nade mną i powiedział: „Widzę, że jest pan inteligentnym człowiekiem, jeśli pan będzie chciał pomocy, to niech pan przyjdzie, postaram się panu pomóc”. Mnie, który czuł się... no, taką ścierką do podłogi.

2 czerwca 1994 roku, Boże Ciało - z kościoła Arki Pana ludzie wyszli na procesję, oni mi przeszkadzali, bo ja toczyłem się do meliny na swoją poranną porcję wódki, żeby się wreszcie przestać trząść. Dla mnie to był zwykły alkoholowy dzień, ja już nie rozróżniałem świąt, do kościoła i na modlitwę było mi za daleko... Ten tłum mnie zagarnął, prowadził mnie tyłem. Nie miałem siły się wyrwać... Chłopcy dzwonili dzwoneczkami, dziewczynki sypały kwiaty, koło mnie przeszedł kapłan. „Jeszcze ten mi przeszkadza!” pomyślałem. A to sam Chrystus wyszedł po mnie na ulicę. Płacząc w myślach, zawołałem: „Boże, przecież ja kiedyś byłem szczęśliwy, dlaczego ja muszę iść na wódkę...”. Na melinie wypiłem dwa kieliszki i do domu. Dziwne. Coś mi wołało: „Jezusie, synu Dawida, ulituj się nade mną!”. Myślę: „Kobierzyn, zwariowałem”. Poszedłem spać. Gdy się obudziłem, jakby mi ktoś mózg wymienił. Pierwsza myśl: „po pomoc!”. Przypomniałem sobie tego kapłana z kolędy i poleciałem na tę parafię św. Judy Tadeusza z wołaniem: „Boże, co to będzie, jak go nie będzie!”. A ten ksiądz po prostu tam na mnie czekał. Drzwi kancelarii były dla mnie otwarte. Kapłan pomógł mi wybrać grupę ludzi zdrowiejących z tej choroby. Poszedłem do przytuliska św. brata Alberta. Właśnie jednego gościa wyprowadzali 
z butelką denaturatu w ręce, dwóch innych dobijało się do bramy, trzeci pluł do judasza... Byłem przerażony, myślałem: „Jak ja mam tu coś zrobić z tym alkoholem, jak tu wszyscy piją!". Uciekłem nad Wisłę. Nie wiem, czemu wróciłem, a jak przyszedłem, znowu kogoś wyprowadzali stamtąd - znowu ucieczka. Za trzecim razem tak się pchali, jakiś chleb rozdawano, że mnie po prostu wepchnęli do środka. Na bramie był brat Alojzy, zacząłem mu ściemniać, że świat taki zły, z pracy mnie wywalili, ojciec nigdy nie powiedział, że mnie kocha, matka ciągle krzyczy i płacze, na końcu coś tam o alkoholu. Brat Alojzy wysłał mnie na mityng AA.

Tak się zaczął nowy rozdział mojego wreszcie prawdziwego, odpowiedzialnego życia. Oskarżałem mego ojca, że on w ogóle nie miał uczuć, że nigdy nie powiedział, że mnie kocha. A dopiero trzy lata po jego śmierci dowiedziałem się, że przez rok chodził do przychodni przeciwalkoholowej, aby ratować syna. Na szczęście zdążyłem mu powiedzieć, że go kocham. Gdy mama została sparaliżowana, tato bardzo się nią opiekował. Złapałem ich wtedy za ręce i nieśmiało zapytałem: „Boże, czemu ja wam nigdy nie powiedziałem, że was kocham?”. Tato zapłakał. A mama pierwszy raz przemówiła, wykrzywioną twarzą: „Kocham cię!”. Przemówiła! Kiedy zacząłem trzeźwieć, próbowałem wziąć życie we własne ręce, ale wylądowałem w przytulisku.

Coś we mnie pękło, powiedziałem sobie: „Ty sam wiesz, czemu tu jesteś!”. Zaczęło mi się układać, dopiero wtedy zobaczyłem, że całe życie nikogo nie doceniałem, liczyłem się tylko ja - pępek świata. Oskarżałem przedtem przede wszystkim mamę, która odgrzewała obiady, ojca, który przeszkadzał pić i odmawiał papierosa. Dziwiło mnie tylko, że kiedy odmawiał, to miał łzy w oczach.

Tam w przytułku zaczęli mnie uczyć wszystkiego, przede wszystkim odpowiedzialności. Gdy dostałem pierwszą wypłatę, to zapomniałem sobie, że trzeba za dom zapłacić, druga mi jakoś przeleciała, ale po trzeciej ojciec dyrektor kazał mi zapłacić. Zobaczyłem, jak alkohol we mnie siedzi, jaki jestem manipulant, nawet nie umiem 
gospodarować pieniędzmi. Paliłem wtedy masę papierosów, przecież to było drogie.

Były też spotkania z Ewangelią. Prowadziła to świecka dziewczyna, pani Małgosia. I ona nieraz pytała: „Kim jest Jezus?”. Inni zawsze to czytali między wierszami, a ja nieustannie pytałem: „Gdzie wy to widzicie?!”. Mordowali mnie przez cztery lata, ale w końcu coś zaczęło wchodzić do tego upartego łba. W tym czasie, kiedy przestałem pić, to w ciągu trzech lat pięć razy byłem w szpitalu psychiatrycznym, tak mi się w głowie mieszało od tego wszystkiego, co nawyrabiałem. Spotkałem tam człowieka, który miał tyle samo lat co ja. Miałem 42 lata, gdy cudownie zostałem ocalony. Najpiękniejsze lata przepiłem, począwszy od siedemnastego roku życia mam czarną dziurę. Ten człowiek miał umysł pięcioletniego dziecka, wyglądał jak cyklop - niby miał dwoje oczu, ale jakoś tak poprzestawiane, jakby na czole miał to oko; był chory na padaczkę, więc chodził na okrągło w kasku, z latareczką, z tornistrem na plecach, nic koło siebie nie umiał zrobić... Wszyscy się z niego śmiali, a ja, nie wiedzieć czemu, zacząłem cierpieć. On poszedł do ustępu, wrócił ze spodniami na dole, nie umiał sobie nawet butów związać, wywalił się, wszyscy współtowarzysze niedoli w Kobierzynie śmiali się, jeden wielki ryk. A ja się wtedy rozpłakałem. Zobaczyłem siebie - takiego połamańca. Podszedłem do niego, zawiązałem buty, podciągnąłem spodnie, a on pocałował mnie w rękę i powiedział: „Zabierz mnie do domu”. Pomyślałem sobie: „Gościu, czego tobie brakuje? Masz wszystko, tylko jednej rzeczy nie masz: nie masz chęci do życia i chęci do roboty”. Znalazłem się w takiej strasznej depresji, że właściwie to myślałem o śmierci. Siłą prowadzili mnie na obiady, nie miałem na nic siły. I usłyszałem, że „wiara czyni cuda”. Od księdza Krzysztofa dostałem taką słowną perełkę na całe życie: „To nie droga jest trudna, to trudności są prawdziwą drogą".

Żeby sobie wyprać ostatnią parę skarpetek, musiałem się najpierw pomodlić w kaplicy. Śmiano się ze mnie, ale że działało, zacząłem coraz częściej tam bywać; tam czułem się najbezpieczniej. Obraz 
Matki Bożej był po lewej stronie, na środku krzyż - bez Chrystusa. Klęczałem, najlepiej po ciemku. Modliłem się - to była dopiero książka życzeń i zażaleń... Potem odmawiałem różaniec - myślałem, że zwariowałem, bo gdy zaczynałem, słyszałem w głowie stek obelg i bluźnierstw. Strasznie się bałem. Pewnej nocy poczułem, że ktoś w kaplicy jest, zapaliłem światło - nie było nikogo. Za drugim razem poczułem ogromy pokój serca. Przestałem się bać! I już wiedziałem On tam jest. Poczułem oddech Boga.

To był przełom. Dostałem siłę, już mnie nikt nie musiał zaganiać do roboty. W tym przytułku zrozumiałem, że taka miała być moja droga - żebym został odarty z całego swego systemu zabezpieczeń. To szczególna łaska Ducha Świętego. Bracia zakonni nas zabierali w różne miejsca - a to do Zakopanego, a to do Częstochowy, a to do Lichenia. Knajpy zamieniłem na takie szczególne miejsca wiary... Niedawno spotkałem kolegę Alka, kiedyś bezdomnego, który prosił, żeby podziękować albertynom. U niego też wszystko się poukładało, rodzina, studia, praca, mocno stanął na nogi.

Zawsze z wdzięcznością wspominam to miejsce - przytułek, bo nie samą bezdomność, której doświadczyłem, i zawsze mnie wkurza, kiedy ktoś mówi: „Ja cię rozumiem”. To nie jest takie proste, nie da się tego zrozumieć. Kiedy przełykałem przez łzy ten łaskawy chleb, czasami stawał mi w gardle... Ale dziś czuję niesamowitą wdzięczność. Musiałem dobić samego dna, aby się odbić i rozwinąć skrzydła. Dzisiaj odzyskałem siebie, swą tożsamość, godność człowieka, godność dziecka Bożego. Mam mieszkanie własnościowe, pracę i cieszę się szacunkiem ludzi. Wreszcie jestem szczęśliwy. Nauczyłem się wielu rzeczy, nauczyłem się modlić. Czytam Biblię. A z Biblią miałem ciekawą przygodę. Do przytuliska trafił Murzyn i ile razy mnie spotkał, tyle razy po angielsku pytał, czy mam swoją Biblię. Uciekałem przed nim, bo ciągle wywracał oczami i pytał, dlaczego ja nie mam swojej Biblii? Tak mnie męczył, że w końcu poszedłem do Jaśka Budziaszka i mu to opowiedziałem. On się roześmiał i przyniósł Biblię. Tak to Pan Bóg działa, że człowie- 
ka z Afryki sprowadził, żebym miał tę swoją Biblię! Wiadomo, na wszystko miałem, na papierosy miałem, na słodycze miałem, ale na Biblię nie - no to mi ją „postawił” za darmo. Dziękuję bardzo! Chwała Panu.

\section{Zakończenie}

W przypowieści o miłosiernym ojcu tata nie chodzi za synem - czeka. Pozwala mu się odłączyć, pocierpieć i czeka na moment, w którym ten się otrząśnie i zacznie szukać. Syn pomyślał, co się stało, i podjął decyzję, że wróci do domu. Wciąż te dwa wątki: pozwolić cierpieć, a z drugiej strony - uszanować godność, dowartościować człowieka. Budować na prawdzie. Na prawdzie, a nie na głaskaniu dziadostwa. 